\title{
Mesenteric tissue for the treatment of septic pelvic complications in the absence of greater omentum
}

\author{
E. J. de Groof ${ }^{1}$ - O. van Ruler ${ }^{1}$ - C. J. Buskens ${ }^{1}$ • P. J. Tanis ${ }^{1}$ - W. A. Bemelman ${ }^{1}$
}

Received: 4 July 2016/Accepted: 12 August 2016/Published online: 2 December 2016

(C) The Author(s) 2016. This article is published with open access at Springerlink.com

\section{Introduction}

A presacral abscess or sinus is a potentially devastating complication. These may result from an infectious disease or post-operative complications such as anastomotic leakage. A persisting presacral sinus may lead to fistula formation $[1,2]$. Salvage surgery may be indicated, and an omentoplasty or myocutaneous flap reconstruction can be used to fill dead space and control local pelvic sepsis [3]. Greater omentum is not always available, and tissue flaps have the risk of flap necrosis. We describe four cases in which mesenteric tissue surrounding either branches of the inferior mesenteric or ileocolic artery was used to fill the pelvis.

\section{Technique}

All patients had a pre-existing deviating ileostomy or colostomy. To resect the remaining rectum or ileal pouchanal anastomosis, a transanal intersphincteric approach was used with thorough debridement of the presacral sinus/ abscess. There was not enough omentum to create an omentoplasty of sufficient length and volume. The colon or ileum was dissected close to the bowel, thereby leaving the recto-sigmoid mesentery or ileocecal mesentery in situ with its vascular supply. Mesentery was fully mobilised and moved towards the pelvic dead space (Fig. 1). Fixation to the pelvic wall and/or pubic bone was performed to

W. A. Bemelman

w.a.bemelman@amc.uva.nl

1 Department of Surgery, Academic Medical Center, PO BOX 22660, 1100 DD Amsterdam, The Netherlands

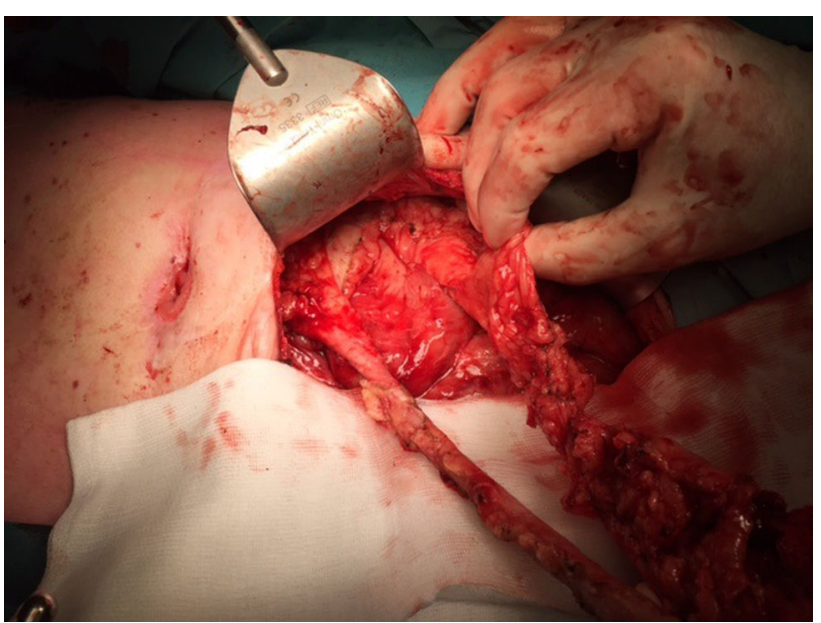

Fig. 1 Male patient (69 years old) with persistent leakage of the coloanal anastomosis treated with resection of the efferent loop of the diverting colostomy and rectal stump with debridement of a presacral abscess. The mesentery was fully mobilised and moved towards the dead space in the pelvic cavity

prevent small bowel loop herniation. Pelvic drains were placed.

\section{Results}

Baseline patient characteristics are displayed in Table 1. In one patient, resection of a coloanal anastomosis was performed for persistent leakage, with a history of iatrogenic rectal perforation after cystoprostatectomy. Another patient had a persistent presacral sinus due to fistulisation from an ileal pouch-anal anastomosis. The third patient also had an ileal pouch-anal anastomosis for ulcerative colitis, but was rediagnosed with Crohn's disease. Indications for pouch excision were persisting pouchitis and cuffitis with perianal 


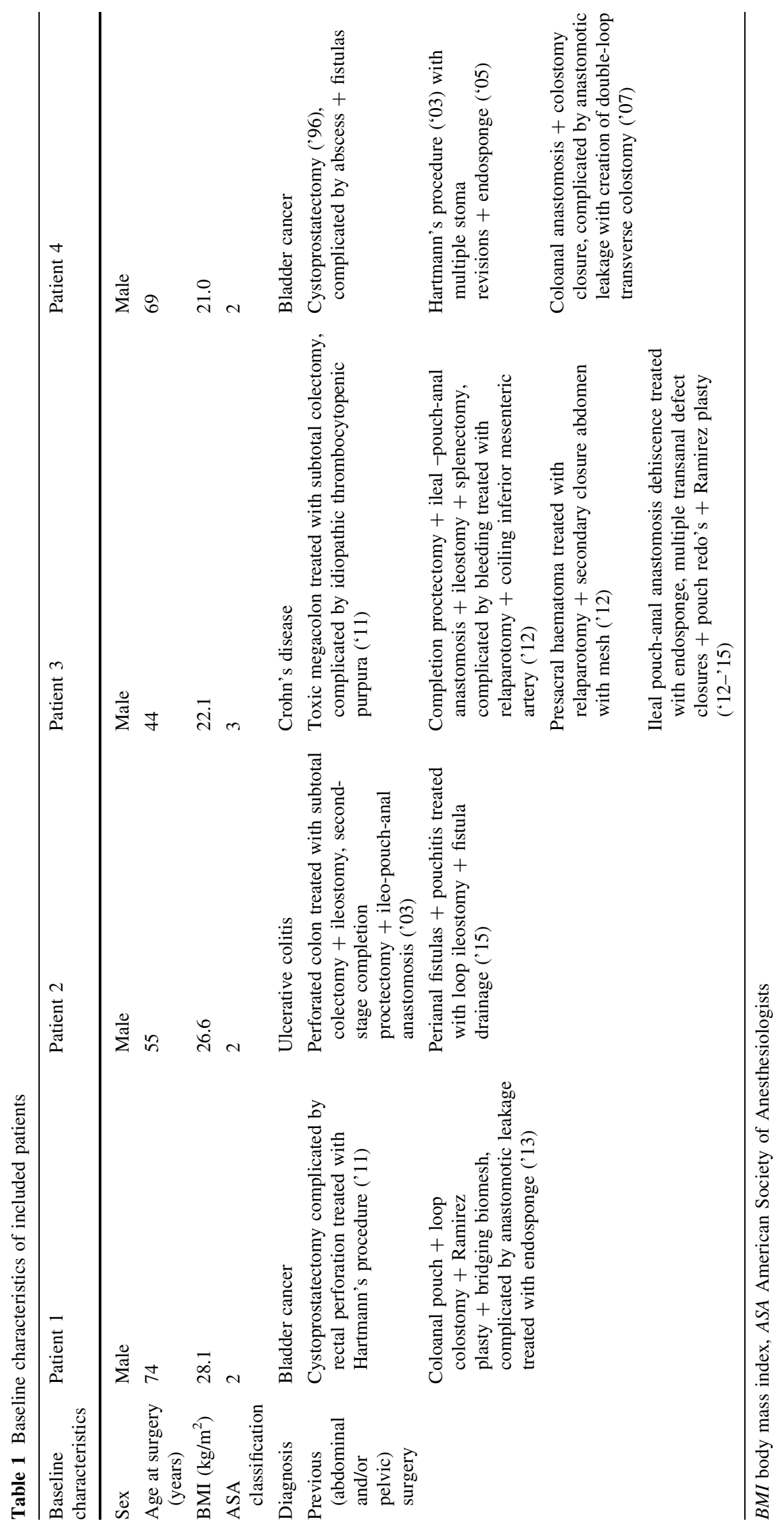


Table 2 Surgical characteristics of included patients

\begin{tabular}{|c|c|c|c|c|}
\hline $\begin{array}{l}\text { Surgical } \\
\text { characteristics }\end{array}$ & Patient 1 & Patient 2 & Patient 3 & Patient 4 \\
\hline Indication & $\begin{array}{l}\text { Persisting leakage coloanal } \\
\text { anastomosis }\end{array}$ & $\begin{array}{l}\text { Ileal pouch-anal } \\
\text { anastomosis with } \\
\text { persistent fistulas }\end{array}$ & $\begin{array}{l}\text { Ileal pouch-anal } \\
\text { anastomosis with } \\
\text { persistent presacral } \\
\text { sinus }\end{array}$ & $\begin{array}{l}\text { Persistent leakage of coloanal } \\
\text { anastomosis }\end{array}$ \\
\hline Surgery & $\begin{array}{l}\text { Resection efferent loop of } \\
\text { diverting colostomy and rectal } \\
\text { stump with debridement of } \\
\text { pelvic abscess }\end{array}$ & $\begin{array}{l}\text { Excision of ileal pouch- } \\
\text { anal anastomosis with } \\
\text { creation of end } \\
\text { ileostomy }\end{array}$ & $\begin{array}{l}\text { Excision of ileal pouch- } \\
\text { anal anastomosis with } \\
\text { creation of end } \\
\text { ileostomy }\end{array}$ & $\begin{array}{l}\text { Resection of efferent loop of } \\
\text { diverting colostomy and rectal } \\
\text { stump with debridement of } \\
\text { presacral abscess }\end{array}$ \\
\hline Approach & Laparotomy & Laparotomy & $\begin{array}{l}\text { Laparotomy and } \\
\text { transanal minimally } \\
\text { invasive surgery }\end{array}$ & $\begin{array}{l}\text { Laparotomy and transanal } \\
\text { minimally invasive surgery }\end{array}$ \\
\hline Setting & Elective & Elective & Elective & Elective \\
\hline Blood loss (ml) & NR & 400 & 100 & 100 \\
\hline
\end{tabular}

$N R$ not reported

Table 3 Post-operative outcomes of included patients

\begin{tabular}{lllll}
\hline Post-operative outcomes & Patient 1 & Patient 2 & Patient 3 & Patient 4 \\
\hline Post-operative stay (days) & 19 & 6 & 25 & 16 \\
Post-operative complications & Pelvic abscess & No & Subhepatic abscess and ileus & Small pelvic abscess \\
Reintervention & Percutaneous drainage & No & $\begin{array}{c}\text { Diagnostic puncture and peripherally inserted } \\
\text { central catheter for total parenteral nutrition }\end{array}$ & No \\
Readmission (within 30 days) & Yes & No & No & No \\
Late complications & Persistent pelvic abscess & No & Granuloma at stoma site & No \\
Follow-up to date (months) & 22 & 4 & 4 & 1 \\
\hline
\end{tabular}

fistulas. The fourth patient had a history of cystoprostatectomy and a Hartmann's procedure, complicated by recurrent abscess and fistula formation from the rectal stump, for which a coloanal reconstruction with diverting colostomy and multiple endosponge procedures were performed.

Surgical details are presented in Table 2. The post-operative course was uneventful in one patient (Table 3). One patient developed a subhepatic abscess, which was punctured. The two remaining patients had persisting pelvic abscesses, treated by antibiotics in one patient, and, in the other, percutaneous drainage which failed necessitating surgical drainage. Eventually, all patients recovered without signs of pelvic infection.

\section{Discussion}

Salvage surgery for pelvic septic complications following colorectal surgery most often dictates radical removal of pelvic bowel structures with a definitive ostomy [4]. Patients undergoing redo surgery are prone to develop recurrent infectious complications. Contaminated pelvic dead space after salvage surgery may progress into a sinus with persistent abscesses and the risk of secondary complications. Previous research suggests that obliterating the pelvic space with an omentoplasty after abdominoperineal resection for rectal cancer results in enhanced perineal wound healing and a decrease in sinus formation due to angiogenesis and enhancement of the inflammatory response [5]. Pelvic dead space obliteration after salvage surgery is also described for this purpose [4]. In the absence of omentum, and considering the morbidity associated with autologous tissue flaps, obliteration of pelvic dead space with viable mesentery of a bowel segment that has to be removed as part of salvage procedures seems to be a valuable alternative. Although one patient had a persistent pelvic abscess, complete pelvic sinus healing was accomplished in all four patients.

More research is necessary to understand the physiological immune responses of mesentery, which may be of value in controlling infectious complications not just for anatomical filling. Availability of mesenteric tissue of adequate length and volume has to be assessed in every 
single patient, but might be preferred over myocutaneous flap reconstructions.

\section{Compliance with ethical standards}

Conflict of interest The authors declare that they have no conflict of interest.

Ethical approval For a retrospective study we did not need to obtain ethical review as with prospective studies or randomized controlled trials. Data could not be lead back to the patients and no questionnaires were sent.

Informed consent All patients, of course, gave informed consent for the surgery and registry.

Open Access This article is distributed under the terms of the Creative Commons Attribution 4.0 International License (http://crea tivecommons.org/licenses/by/4.0/), which permits unrestricted use, distribution, and reproduction in any medium, provided you give appropriate credit to the original author(s) and the source, provide a link to the Creative Commons license, and indicate if changes were made.

\section{References}

1. Heuschen UA, Allemeyer EH, Hinz U, Lucas M, Herfarth C, Heuschen G (2002) Outcome after septic complications in J pouch procedures. Br J Surg 89:194-200

2. Chadwick MA, Vieten D, Pettitt E, Dixon AR, Roe AM (2006) Short course preoperative radiotherapy is the single most important risk factor for perineal wound complications after abdominoperineal excision of the rectum. Colorectal Dis 8:756-761

3. Hultman CS, Sherrill MA, Halvorson EG et al (2010) Utility of the omentum in pelvic floor reconstruction following resection of anorectal malignancy: patient selection, technical caveats, and clinical outcomes. Ann Plast Surg 64:559-562

4. Musters GD, Borstlap WA, Bemelman WA, Buskens CJ, Tanis PJ (2016) Intersphincteric completion proctectomy with omentoplasty for chronic presacral sinus after low anterior resection for rectal cancer. Colorectal Dis 18:147-154

5. Nilsson PJ (2006) Omentoplasty in abdominoperineal resection: a review of the literature using a systematic approach. Dis Colon Rectum 49:1354-1361 